\title{
Grassland with tradition: sampling across several scientific disciplines
}

\author{
Monika Janišová 1 , Anamaria Iuga ${ }^{2}$, Cosmin Marius Ivașcu ${ }^{3}$, Martin Magnes $^{4}$ \\ 1 Institute of Botany, Plant Science and Biodiversity Center, Slovak Academy of Sciences, Banská Bystrica, Slovakia \\ 2 Muzeul Național al Țăranului Român, Bucharest, Romania \\ 3 Department of Biology-Chemistry, West University of Timișoara, Timișoara, Romania \\ 4 Department of Plant Sciences, Institute of Biology, University of Graz, Graz, Austria \\ Corresponding author: Monika Janišová (monika.janisova@gmail.com)
}

Academic editor: Flavia Landucci • Received 13 November 2020 • Accepted 2 January 2021 • Published 17 February 2021

\begin{abstract}
The traditional, low-input use of grassland in Central and Eastern Europe has provided high-quality food, clothing and manure for millennia. As an outcome of sustainable low-intensity agriculture, some rural areas have globally significant species richness. Traditional farming is still well preserved in several regions of the Carpathian Mountains. This is a unique opportunity to use the wisdom of our ancestors to keep grassland biodiversity for our descendants. We present a sampling methodology to survey traditionally managed grassland ecosystems holistically, including abiotic, biological and cultural phenomena, and reflect thus the multidimensionality of traditional farming. Our main objective was to reveal the connection between particular management practices and precisely measured plot plant diversity. Our motivation was to identify traditional farming approaches that result in both high biodiversity and sustainable grassland utilization in particular region, and confirm their impact also using statistical tests. The multitaxon vegetation sampling at seven spatial scales combined with soil analyses, detailed land-use information derived from interviews with the land parcel owners, satellite pictures and historical materials provide potentially valuable data for several scientific disciplines including syntaxonomy, plant ecology, environmental anthropology and ethnology. Examples of grassland management practices based on traditional ecological knowledge can serve as an inspiration for developing modern biodiversity conservation strategies applicable for rural regions. The database Grassland with Tradition is registered in Global Index of Vegetation-Plot Databases (GIVD) with the identifier ID EU-00-032. To date it contains data from 31 study sites in 7 countries (Austria, Czech Republic, Slovakia, Hungary, Poland, Romania, Ukraine).
\end{abstract}

Syntaxonomic reference: Mucina et al. (2016).

\section{Keywords}

ecology, ethnology, grassland management, history, land use, low-input farming, local ecological knowledge, meadow, pasture, plant diversity, sampling approach, typology, vegetation-plot database

\section{Introduction}

A standard approach to vegetation survey is a single visit of the selected study site, particularly when the aim is classification of a certain vegetation type. Approaches based on re-sampling, permanent study plots or manipulative experiments allow for the study of ecological processes and temporal changes to vegetation. However, some goals of vegetation survey cannot be reached without cooperation with other scientific disciplines. This is particularly the case for studies of habitats that depend on human influence, such as traditionally managed grassland. 
All semi-natural grassland habitats are partly or fully dependent on agricultural management (Halada et al. 2011) and their land-use history is usually crucial for conservation of their biodiversity (Diacon-Bolli et al. 2012; Bürgi et al. 2013). Traditional farming conditioned the emergence of all semi-natural grasslands in Europe, as it has contributed to forming their species composition and diversity over several centuries or even millennia (Bonn and Poschlod 1998; Poschlod and WallisDeVries 2002; Poschlod et al. 2009; Hejcman et al. 2013; Poschlod 2015). Grassland history is reflected in present grassland, but it is difficult to detect its traces clearly. Moreover, in traditional landscapes, each piece of land has different ownership structure, different management schemes and different histories (Babai and Molnár 2014; Kun et al. 2019), and it is not easy to make generalized management recommendations. The simple typology distinguishing between meadows (mown grasslands) and pastures (grazed grasslands) used nowadays in Western Europe does not cover the whole scale of applied management techniques and does not reflect the multidimensionality of traditional farming. It is often the case that each traditional land parcel represents a category of its own (cf. Janišová et al. 2020).

\section{Traditional farming and local ecological knowl- edge}

Traditional farming includes various types of low-input land utilization on private farms. This type of farming typically occurs within small parcels belonging usually to a single family, or, in some cases, to a commune or farmer associations. Different owners usually apply different farming practices according to the family customs and personal traditional knowledge, so that the landscape itself is very diverse (see also Johansen et al. 2019; Wehn et al. 2019). However, neither the size of land parcels nor the level of labour mechanization is decisive for our delimitation of traditional farming. The most important criterion is rural culture and traditions passed down from generation to generation, which underpin local farming approaches. In this aspect, traditional grassland management differs from modern high-input grassland management, as well as from low-intensity conservation grassland management. The main difference between traditional grassland management and a conservation approach is that local farmers prioritise temporal stability in fodder quantity and quality over biodiversity, which is the main assumption of a long-term ecological sustainability (Janišová et al. 2020). In most European countries, traditional farming is no longer practiced; it has been either substantially modified or replaced by modern farming approaches. However, in some remote mountain areas and in several regions of Eastern Europe, historic land use patterns and farming approaches have survived to the present day (Figure 1). Similarly, the local-ecological knowledge of the rural inhabitants has been preserved in these areas, which may become a tool for effective conservation of
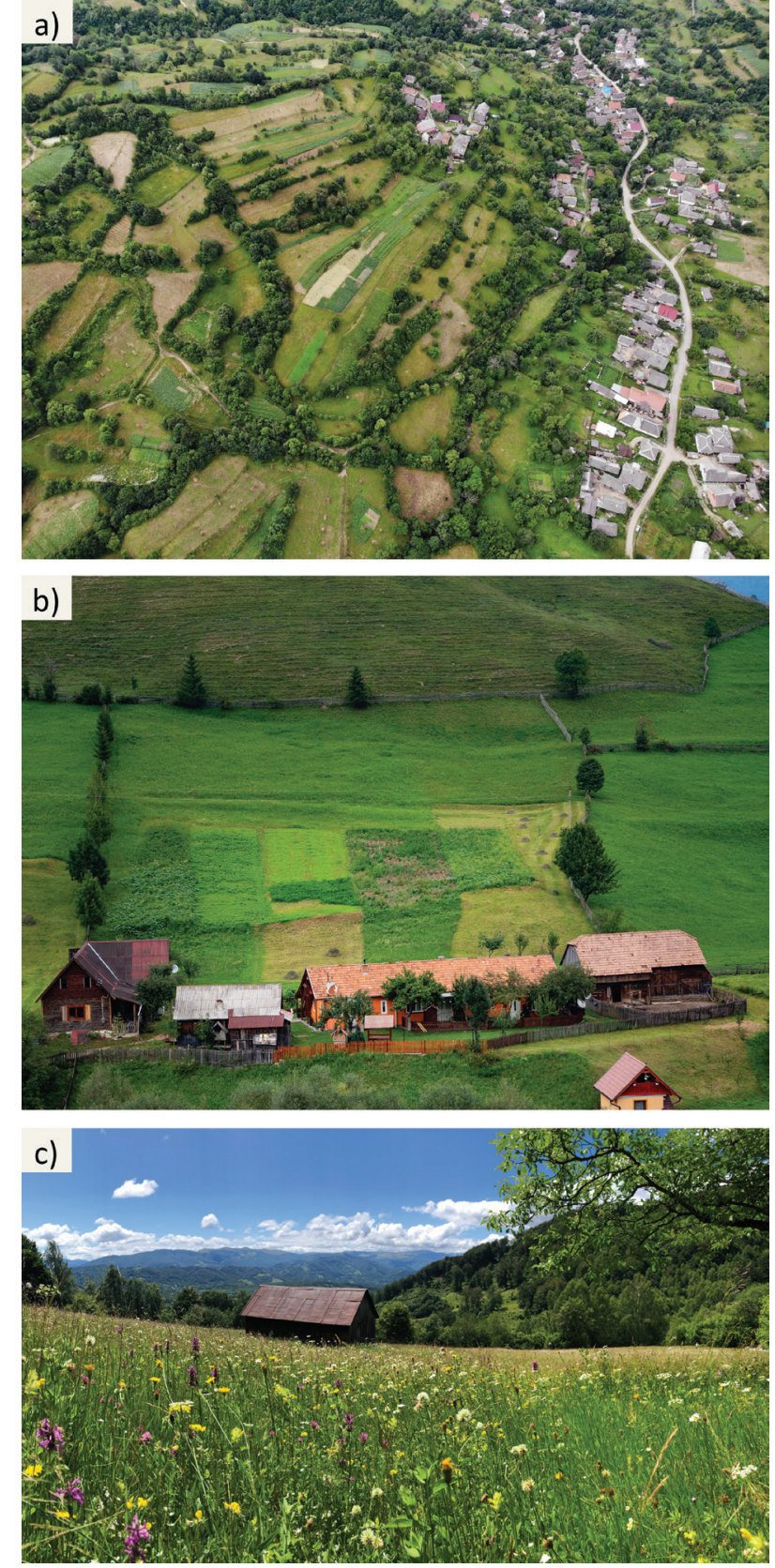

Figure 1. Traditional farming can maintain high levels of biodiversity and the Carpathian bio-cultural heritage is a well of wisdom for modern biodiversity conservation. Traditionally managed grasslands are often small-sized and very specific in their management. a) Domashyn, Ukraine, June 2018, M. Khytruk; b) Valea Rece, Romania, August 2019, M. Janišová; c) Bănița, Romania, June 2020, M. Janišová.

grassland biodiversity (Babai and Molnár 2014; Ivașcu et al. 2016; Kun et al. 2019; Janišová et al. 2020).

\section{Anthropologic research status in the Carpathi- an countries}

Studies of traditional farming systems are well represented in the fields of cultural and environmental anthropology 
and its branches of ethnography (the in-depth study of a particular cultural group) and ethnology (the comparative study of ethnographic data, society and culture). For example, Romania has a long history of ethnographic research of peasant households and beliefs concerning the natural environment. Since the mid- $19^{\text {th }}$ century, folk knowledge regarding plants was systematically studied, firstly by folklorists such as Simeon Mangiuca (18311890) and Simion Florea Marian (1847-1907). The latter compiled an impressive Encyclopaedia of traditional culture with information concerning plants used by the local Romanian population, in a massive manuscript (12.000 pages and a herbarium, see Marian 2008-2010). Later, with the development of ethnobotany, well-known Romanian botanists conducted studies (Borza 1935, 1968) and some ethnologists trained in botany (Butură 1979). Despite communist censorship, a considerable number of studies were published starting from the mid $-19^{\text {th }}$ century up until 1990, after which new studies were scarce and were carried out by only few researchers (e.g., Drăgulescu 2013, for Southern Transylvania). However, Romanian ethnobotanical research focuses mostly on the linguistic topics (vernacular names and its origin), empirical use, and spiritual importance of plants. Data on the traditional management of hay meadows and other grasslands, or the local economic importance of certain meadow-associated wild plant species, are absent. While the number of ethnographic and ethnological studies on the material culture of the peasant population in Romania increased in the $20^{\text {th }}$ century, these studies provide limited information regarding traditional grassland management (hay meadows and pastures). Detailed information about tools and constructions can be found in Butură (1978), whilst in Vuia (1964) we find the first and the most important classification of pastoral practices for Romania.

In the aforementioned studies, the information on grassland use is scarce and can be partially conceived from the other agricultural practices described. For example, piecemeal information on traditional agricultural practices can be found in studies concerning beliefs and/or feasts of the Romanian villages that involve work regulations, such as interdictions and calendar of the labours (see Pamfile 1997, with the first edition in 1914; Marian 1994, with the first edition in 1898-1899). Important contributions can also be found from the interwar Rural Sociology School studies, that occurred between 1925-1948, under the guidance of Dimitrie Gusti (1880-1955). The main method used by sociologists was the monographic research (for example Conea 1940; Ionica 1944; Bernea 1985). The topic of hay meadow management was first addressed by the Rural Sociology School of Bucharest in their exhaustive monograph from Clopotiva (Conea 1944, which described the local mowing time and some other practices related to hay meadow management) and incidentally in the complex studies from Drăguș (Bărbat 1944).

The situation is fairly similar in the Ukrainian Carpathians. Despite active research by the ethnographers and geographers, studies on traditional farming practices are scarce. An exception is the widely studied Carpathian pastoralism (e.g. Kubijovyč 1936; Podolák 1966; Tyvodar 1994). Recently, some topics, such as various aspects of haymaking traditions and constructions, or glade farming, were studied by Igor Boiko and Janusz Łach (Boiko 2008, 2009a, b; Boiko and Łach 2020).

Within the Western Carpathians, most ethnographical studies were published during the 1960s and 1970s by Polish and Slovak authors. Bronisława Kopczyńska-Jaworska focussed mainly on mountain shepherding traditions and undertook studies in Poland, Slovakia and Romania (e.g., Kopczyńska-Jaworska 1959, 1961). In the 1960s, Ján Podolák developed a methodological manual for ethnographic research of livestock farming in Slovakia (Podolák 1962), which, besides the detailed description of grassland management practices, included a basic typology of traditional meadows and pastures. His detailed regional studies (e.g. Podolák 1961) as well as his national overviews (Podolák 1965, 2008) contributed significantly to recent knowledge on traditional grassland management practices.

Meanwhile, traditional rural cultures and local traditions became extinct in substantial areas of the Carpathian Mountains, limiting further ethnological research. Recently, traditional farming systems and local-ecological knowledge concerning meadows and pastures have been of interest for ethnologists (Boiko 2008, 2009a, b; Fruntelată et al. 2016; Iuga 2016 ; Boiko and Łach 2020), but also for botanical, agricultural, and landscape-focussed researchers. Numerous studies have taken place in the Carpathian regions with well-maintained traditional agriculture (Akeroyd and Page 2006, 2011; Dahlström et al. 2013; Babai and Molnár 2014, 2016; Biró et al. 2014; Molnár et al. 2015; Plieninger et al. 2015; Hartel et al. 2016; Ivașcu et al. 2016, 2018; Sõukand and Pieroni 2016; Špulerová et al. 2019; Kun et al. 2019). Some of these studies are the result of joint research: either a collaboration by biologists and ethnologists, or biologists who recognize the importance of integrating social aspects into landscape studies. This type of scientific approach was encouraged by some of the founding fathers of Romanian biology even at the beginning of the $20^{\text {th }}$ century (like Antipa 1916), or by other biologists even later (Filipașcu 1981) but has been limited in its uptake. The findings of the aforementioned studies show how the collaboration between biology and ethnology is desirable and beneficial for both disciplines. We therefore see a need to develop an interdisciplinary approach to survey the still maintained traditionally managed grassland ecosystems holistically, including abiotic, biological and cultural phenomena, and reflect thus the multidimensionality of traditional farming.

\section{Basic aims of our study approach}

1. Survey of vegetation composition and diversity in traditionally managed grasslands. Recording species composition of vascular plants, bryophytes and lichens at seven spatial scales together with 
environmental factors. Estimation of species richness, beta diversity and species pool in grasslands of each study site.

2. Record the local bio-cultural heritage and traditional ecological knowledge of the particular region.

3. Explanation of the impact of each single management practice used in traditional agriculture on plant species composition and diversity parameters at the plot level. Understanding the interaction of different management measures and their impacts on plant biodiversity and land productivity.

4. Clarification of the impacts of historical land use and landscape parameters on the structure, composition and diversity of current grassland vegetation. Examination of the relationship between phytosociological grassland classification and grassland typology based on factors other than floristic criteria, such as grassland location, its original purpose, historical land use and applied management practices.

\section{Outline of our study approach}

We developed a specific methodological approach to study traditionally managed grassland in the Carpathian Mountains which encompasses most of its context-specific characteristics. It includes the study of biological objects (plants, vegetation and their formative environment) as well as sociological objects (people, human communities and rural cultures). Therefore, it combines several scientific disciplines: botany and ecology with anthropology and history.
The described methodology has been developed and first tested in 2017. Since then, it was customized and applied to study bio-cultural heritage in 31 sites during two projects (NGS-288R-18, VEGA 02/0095/19). While the inspiration for botanical sampling of plant diversity using the nested-plot-series comes from the standard EDGG methodology (Dengler et al. 2016), our approach includes novel aspects such as broadening the scale to a site level, including the study of current grassland management practices by interviewing plot owners, gathering local ecological knowledge in particular region, and including historical information. In the following sections we describe the different elements of our methodology and provide recommendations for their successful implementation.

\section{Site and plot selection}

The study sites are to be selected in regions with long-term extensively managed grasslands (Figure 1). For the purpose of our study, the site is defined as a circle with an area of $25 \mathrm{~km}^{2}$ with the proportion of managed rural landscape being at least $10 \%$ (Figure 2). In accordance with the study focus, the sites may represent different situations along the elevation gradient, different bedrock types or different political and agricultural histories within the investigated area (Table 1).

Instead of preferential plot selection within a site, a stratified random plot selection is applied in our approach. As land-use type is frequently determined by the terrain configuration and topography, the stratification is based exactly on these criteria. To maximise the variability in

Table 1. Country overview of site and plot numbers, elevation range, geology, typology and phytosociological affiliation of grasslands sampled as of 31 October 2020.

\begin{tabular}{|c|c|c|c|c|c|c|c|c|c|c|c|c|c|}
\hline \multirow[b]{2}{*}{ Country } & \multirow[b]{2}{*}{$\begin{array}{l}\text { Number } \\
\text { of sites }\end{array}$} & \multirow[b]{2}{*}{$\begin{array}{l}\text { Number } \\
\text { of plots }\end{array}$} & \multirow[b]{2}{*}{$\begin{array}{l}\text { Elevation } \\
\text { range }(m)\end{array}$} & \multirow[b]{2}{*}{ Geological bedrock } & \multicolumn{5}{|c|}{ Typology based on prevailing management schemes } & \multicolumn{4}{|c|}{ Phytosociological affiliation to classes } \\
\hline & & & & & 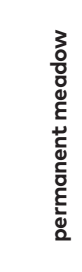 & 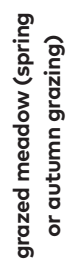 & 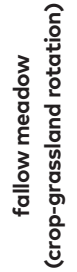 & 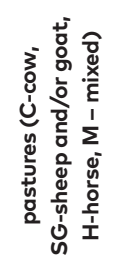 & 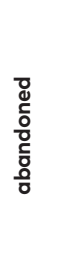 & 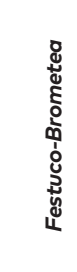 & 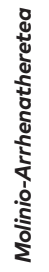 & 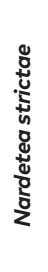 & 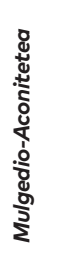 \\
\hline Austria & 1 & 6 & $235-473$ & limestone & 0 & 0 & 1 & $3 \mathrm{SG}, 1 \mathrm{H}$ & 1 & 5 & 1 & 0 & 0 \\
\hline $\begin{array}{l}\text { Czech } \\
\text { Republic }\end{array}$ & 1 & 6 & $377-544$ & flysch & 4 & 0 & 2 & & 0 & 6 & 0 & 0 & 0 \\
\hline Hungary & 2 & 12 & $147-556$ & $\begin{array}{l}\text { limestone, loess, } \\
\text { sediments }\end{array}$ & 2 & 1 & 0 & $\begin{array}{c}2 \mathrm{C}, 1 \mathrm{SG} \\
2 \mathrm{H}\end{array}$ & 4 & 11 & 0 & 1 & 0 \\
\hline Poland & 1 & 6 & $904-1020$ & flysch & 0 & 1 & 2 & $2 \mathrm{C}$ & 1 & 0 & 5 & 1 & 0 \\
\hline Romania & 16 & 96 & 170-1330 & $\begin{array}{l}\text { flysch, limestone, } \\
\text { volcanic, acidic plu- } \\
\text { tonic, sediments }\end{array}$ & 2 & 40 & 9 & $\begin{array}{l}11 \mathrm{C}, 20 \\
S G, 13 \mathrm{M}\end{array}$ & 1 & 16 & 43 & 37 & 0 \\
\hline Slovakia & 6 & 36 & $190-1422$ & $\begin{array}{l}\text { limestone, volcanic, } \\
\text { acidic plutonic, } \\
\text { flysch, sediments }\end{array}$ & 3 & 3 & 6 & $\begin{array}{c}5 \mathrm{C}_{1} 6 \mathrm{SG} \\
5 \mathrm{M}\end{array}$ & 8 & 18 & 12 & 4 & 2 \\
\hline Ukraine & 4 & 24 & $250-1053$ & $\begin{array}{l}\text { flysch, loess, sedi- } \\
\text { ments }\end{array}$ & 2 & 6 & 2 & $\begin{array}{c}4 \mathrm{C}, 1 \mathrm{SG} \\
4 \mathrm{M}\end{array}$ & 5 & 2 & 18 & 4 & 0 \\
\hline All & 31 & 186 & $147-1422$ & & 13 & 50 & 22 & 80 & 21 & 58 & 79 & 47 & 2 \\
\hline
\end{tabular}



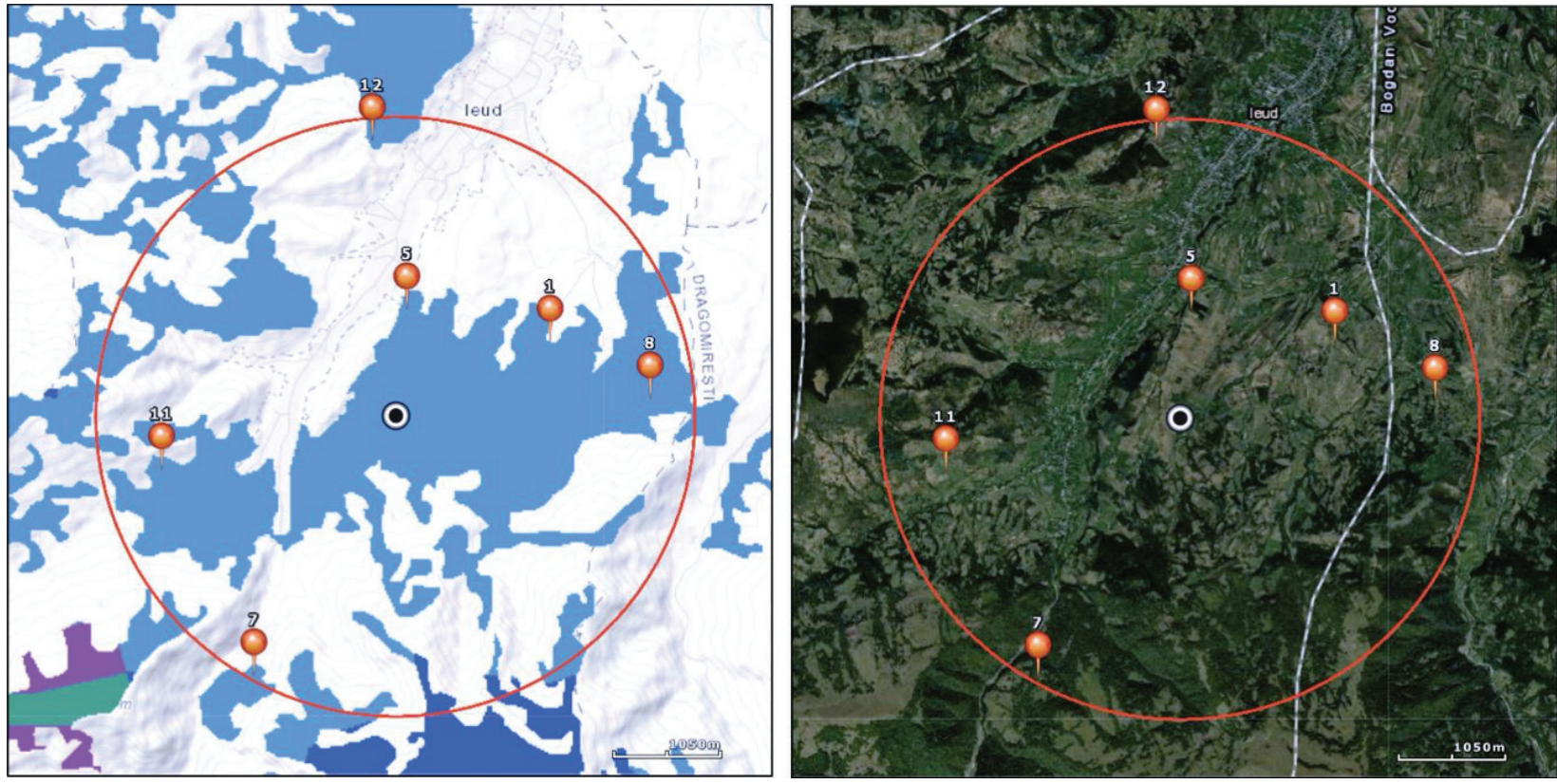

Figure 2. Sampling design within a site. Design consists of a circle of $25 \mathrm{~km}^{2}$ with a minimum of $10 \%$ managed grassland area. Topographic map is used for stratified random selection of sampling plots (red pins with numbers): two in a flat area, one on a moderate W-N-E slope, one on a steep W-N-E slope, one on a moderate E-S-W slope and one on a steep E-S-W slope. Sampling plots are selected exclusively in the CORINE grassland habitats (blue-coloured patches) and a satellite map is used to check the active land-use and avoid abandoned land parcels.

vegetation composition on plots, each site is stratified by slope inclination (flat, moderate, steep) and slope exposition (W-N-E vs. E-S-W). In each combination of inclination and exposition, a series of 7 nested plots of increasing size (Figure 3 ) is randomly placed in a homogeneous veg-

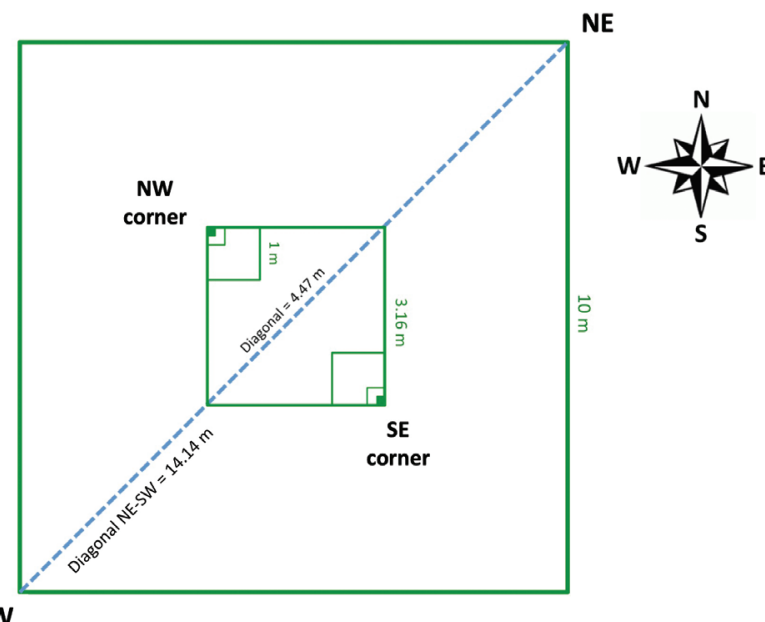

SW

Figure 3. Arrangement of nested plots covering seven spatial scales. The sampling plots are established from the diagonal; after setting the location of the outer NE and SW corners, the inner NE and SW corners are set at 483 and $930 \mathrm{~cm}$. Then the measuring tape is used to fix the $100-\mathrm{m}^{2}$ plot and a special rope with nodes is used to fix the $10-\mathrm{m}^{2}$ and the two $1-\mathrm{m}^{2}$ plots. The 1- $\mathrm{m}^{2} \mathrm{sam}-$ pling plots are placed in the NW and SE corners of the $10-\mathrm{m}^{2}$ plot and their outer corners are used for permanent marking by metal nuts of $20 \mathrm{~mm}$ (NW corner) and $24 \mathrm{~mm}$ (SE corner) buried to a depth of $5 \mathrm{~cm}$. etation patch. Six nested-plot series are thus placed within each site (Figure 2): two in a flat area, one on a moderate $\mathrm{W}-\mathrm{N}-\mathrm{E}$ slope, one on a steep $\mathrm{W}-\mathrm{N}-\mathrm{E}$ slope, one on a moderate E-S-W slope and one on a steep E-S-W slope. For our specific purpose, flat areas have inclination up to $5^{\circ}$, moderate slopes between 5 and $25^{\circ}$, and steep slopes above $25^{\circ}$ (for flatter sites a threshold of $15^{\circ}$ is used). As the plot selection is made a priori, two sets of coordinates are prepared for each site: 1) six sampling coordinates and 2) six reserve coordinates. If during the sampling the pre-selected location is found unsuitable for sampling due to various reasons (lack of access, land destruction, freshly ploughed, etc.) the reserve plot coordinates are used within the given stratification category.

\section{Plot-scale plant diversity sampling}

During the fieldwork, the location of the predetermined coordinates is identified and the actual vegetation is checked for homogeneity before a nested-plot-series is established. The nested plots cover seven spatial scales $\left(0.0001 \mathrm{~m}^{2}, 0.001 \mathrm{~m}^{2}, 0.01 \mathrm{~m}^{2}, 0.1 \mathrm{~m}^{2}, 1 \mathrm{~m}^{2}, 10 \mathrm{~m}^{2}, 100 \mathrm{~m}^{2}\right)$ and their arrangement is shown in Figure 3 . In each of the nested plots, the shoot presence of all species of vascular plants, bryophytes and lichens is recorded. Species relative abundance is estimated visually as a percentage cover in $10-\mathrm{m}^{2}$ plots. For this plot size, the detailed environmental data are obtained. Height of the herb layer is measured at five points - in the middle of the edges and in the plot centre. Percentage cover of herb layer, cryptogam layer and bare soil (plot surface not covered 


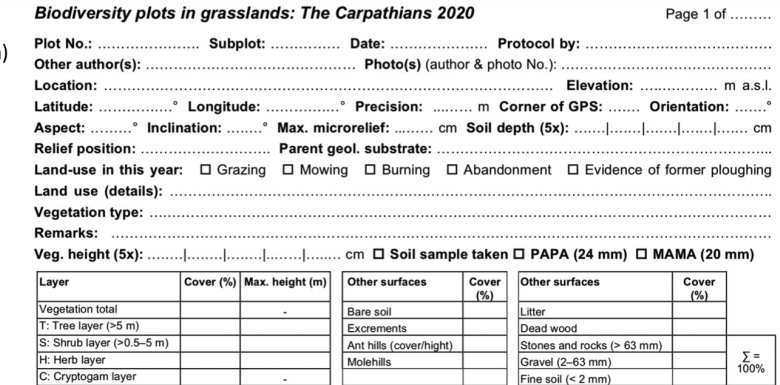

b)
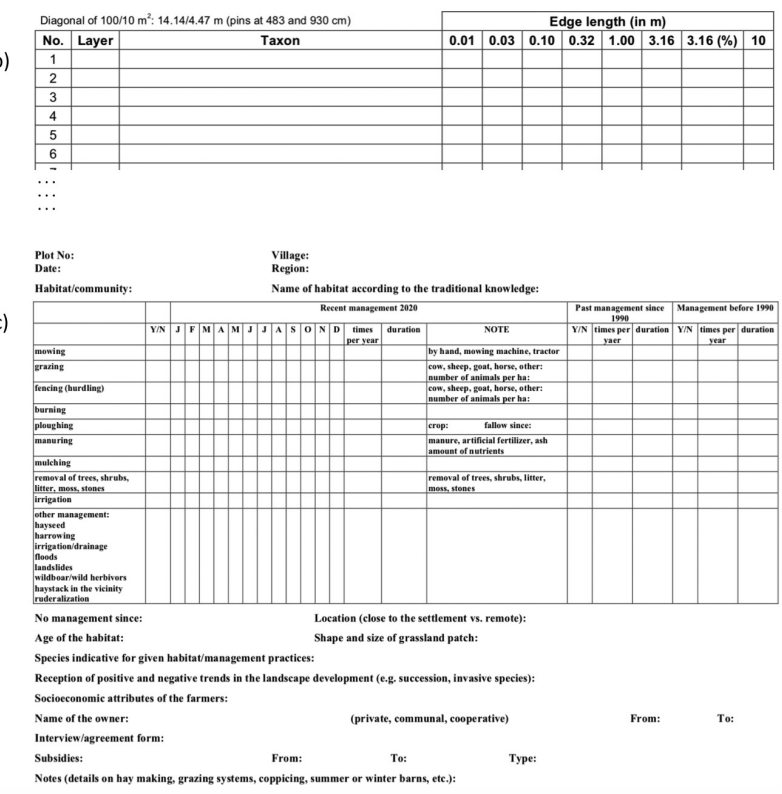

Figure 4. Example of a form used during the fieldwork: a) header data, b) species data and c) land use data.

by vegetation) are estimated and other details on the particular vegetation and surrounding location are recorded in a purpose-designed form (Figure 4). Sampling equipment also includes a camera for documentation of the actual vegetation before the sampling start, GPS for precise measurement of SE and NW coordinates, and some other tools shown in Figure 5.

\section{Data on topography, climate and soil}

During the fieldwork, topography of each $10-\mathrm{m}^{2}$ plot is characterised by elevation $(\mathrm{m})$, inclination $\left(^{\circ}\right)$, and $\mathrm{mi}-$ crorelief (small-scale variability of microtopography expressed as a deviation from a smooth plane in $\mathrm{cm}$ ). Further topographic and climatic data can be calculated a posteriori (e.g. calculation of solar radiation from the latitude, slope and aspect data is possible using the approach of McCune (2007)) or obtained from specialized databases (e.g. mean annual temperature, annual precipitation sum, precipitation of the driest quarter, and other climatic variables can be obtained from the WorldClim (Hijmans et al. 2005; http://www.worldclim.org/) or Chelsa (https:// chelsa-climate.org) databases. Soil depth is measured on each plot at five random points with a steel $\operatorname{rod}$ of $1 \mathrm{~cm}$ diameter. Cover of stones and rocks (particle size diameter $>63 \mathrm{~mm}$ ) and cover of gravel (particle size diameter
2-63 $\mathrm{mm}$ ) is estimated on the plot surface (\%). A mixed soil sample of the uppermost $10 \mathrm{~cm}$ of the mineral soil is taken from five random locations. Air-dried soil samples are analysed in the lab for the following soil parameters: $\mathrm{pH}$ (measured in $\mathrm{KCl}$ ), phosphorus $(\mathrm{P})$, potassium $(\mathrm{K})$ and magnesium $(\mathrm{Mg})$ content in $\mathrm{mg} / \mathrm{kg}$, and calcium $(\mathrm{Ca})$, organic carbon $(\mathrm{C})$, and total nitrogen $(\mathrm{N})$ content in $\mathrm{g} / \mathrm{kg}$. Humus soil content is calculated from the organic carbon content. The $\mathrm{C} / \mathrm{N}$ ratio is calculated as a surrogate of soil accessible nutrients.

\section{Data on management practices}

Basic information on the management practices is obtained during the fieldwork using semi-structured outdoor or indoor interviews with the local farmers and landowners (Molnár et al. 2008). Our questions (see the section on question guidelines for the details) focus on agricultural practices used recently (since 2010) and during the two historical periods, 1950-1990 (the period of centrally planned economy in all investigated countries except Austria) and 1990-2010 (the period of market economy in all investigated countries). Based on the information from landowners and/or their neighbours we were able to derive several management variables with potential short- or long-term effects on grassland ecosystems, including the long-term effect of mowing, grazing, burning or ploughing, management stability, or the cumulative impact of recent traditional management practices which reflects both their heterogeneity and frequency. The cover of litter (cover of dead biomass on the plot surface) is estimated during the field sampling and can be used as a surrogate of grassland abandonment. Further important management variables include type of grazing animal(s) (e.g. horse, cow, sheep, goat, pig, goose), type of grazing system (e.g. spring grazing, autumn grazing, combination of spring and autumn grazing, whole-season grazing in enclosures, common pasture with whole-season free grazing, whole-season herding with a shepherd, folding/corralling), year of the last ploughing and the type of $\operatorname{crop}(\mathrm{s})$ grown at that time.

\section{Data on landscape structure and heterogeneity}

In addition to the management variables, we derived several variables that characterise the surrounding landscape and reflect the local historical grassland development. Along with the size of the actual land parcel around the sampling plot, we calculated the mean size of grassland parcels (in $\mathrm{km}^{2}$ ) within $1-\mathrm{km}^{2}$ plot surroundings (a circle with a radius of $0.564 \mathrm{~km}$ centred at the plot) and the distance (in $\mathrm{m}$ ) of the sampling plot to the nearest forest or hedge, using the satellite images (Google Earth). Proportion of non-forest habitats and habitat diversity in $4-\mathrm{km}^{2}$ plot surroundings (a circle with a radius of $1.128 \mathrm{~km}$ centred at the plot) were derived from the CORINE land cover maps with spatial resolution of 10-50 m (Bossard 

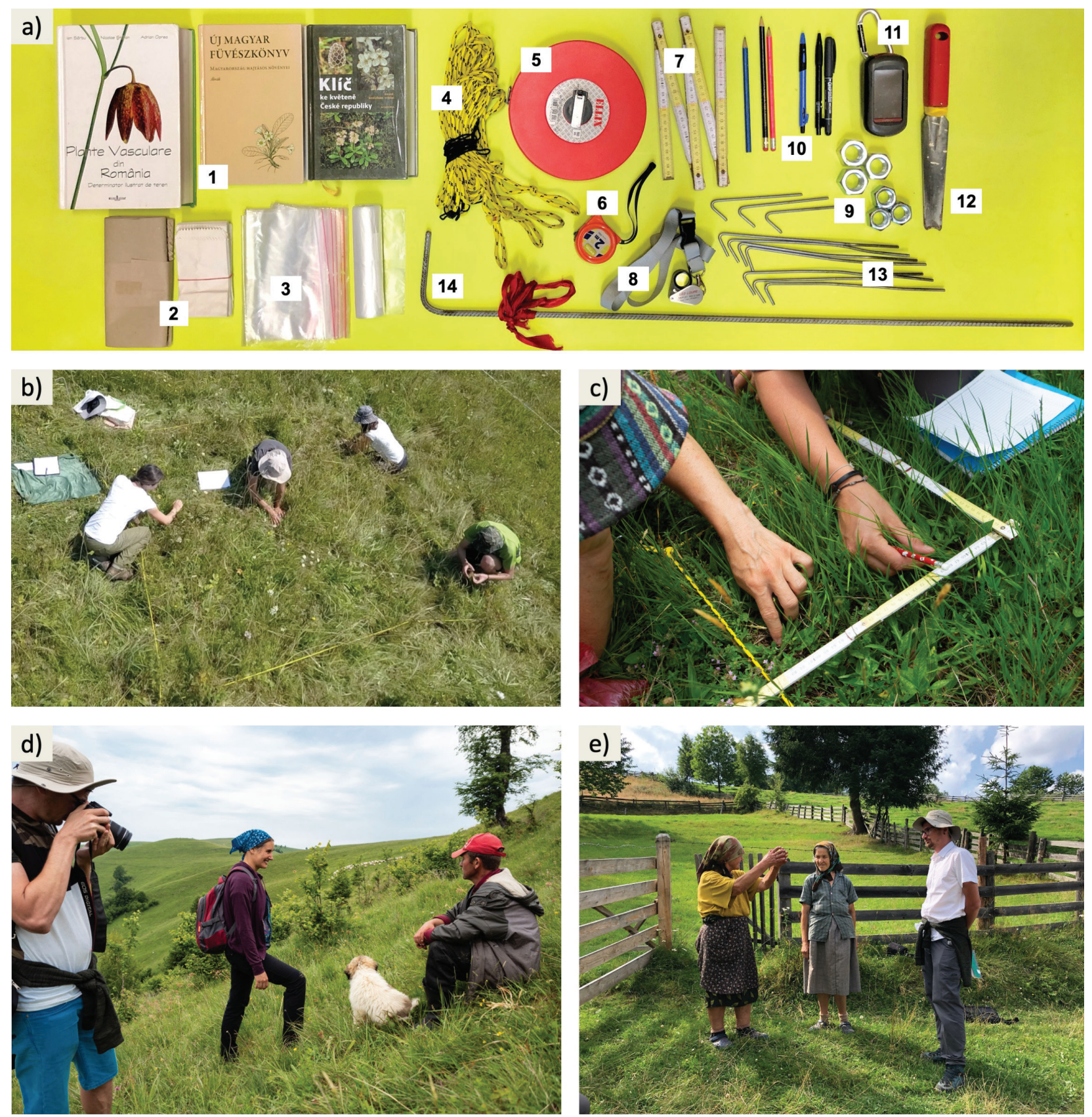

Figure 5. a) Field equipment for biodiversity sampling includes 1: determination keys for local flora, 2: paper bags for soil and cryptogam samples, 3: plastic bags for plants to be determined later, 4: rope with nodes to allocate the small-sized plots, 5: 50-m long measuring tape for establishing the 100- $\mathrm{m}^{2} \mathrm{plot}, 6$ and 7: 2-m long measuring tape or folding meter for defining the smallest plots and for measuring soil depth and plant height, 8: magnifying glass for plant identification, 9: metal nuts of different size for fixing the corners, 10: writing tools, 11: GPS device, 12: shovel for taking soil samples, 13: tent pegs for fastening the rope, 14: steel rod to measure soil depth. b) Recording of the above-ground vascular plants, bryophytes and lichens starts at $1 \mathrm{~cm}^{2}$ of the SE and NW corners in the 10 -m $\mathrm{m}^{2}$ plots. It takes about 3 hours to inspect the whole area, but the time can differ depending on the size of the team and type of vegetation. Rzepiska, Poland, August 2018, M. Chilinski. c) The biggest challenge during the vegetation sampling is to identify each single stem or leaf. Șurdești, Romania, June 2018, K. Nurowska. d) Ethnological part of the vegetation survey builds on traditional ecological knowledge of local people. leud, Romania, June 2018, M. Janišová; e) Outdoor interview with local inhabitants reveals valuable details on the sampled land parcel as well as on the farming system in the village. Mărișel, Romania, August 2019, M. Janišová.

et al. 2000). The 26 habitat classes distinguished in the plot neighbourhoods were combined into five habitat categories (water, non-forest, forest, agricultural, artificial) according to Janišová et al. (2014). The index of habitat diversity was calculated for each plot surroundings, based on the cover of 5 habitat categories in the plot neighbourhood as $\mathrm{H}=-\sum p_{i} \ln p_{i}$ where $p_{i}$ is the proportion of each habitat category. 


\section{Historical land-use information}

Historical data on particular grassland parcels can be obtained from historical maps and, more recently, orthophotos (Figure 6). In our study, we used the georeferenced historical maps from the three military surveys of the Habsburg empire: Josephinische, Franziszeische and Franzisco-Josephinische Landesaufnahmen (https://mapire.eu/en/; Timár et al. 2010). These maps are available for the entire territory of the Carpathians, although the particular region might have changed its state affiliation several times during the last 250 years. For most of the map sheets, cropland and grassland area can be distinguished, the latter usually differentiated between meadows and pastures. Based on these data, we estimated the approximate grassland age of the studied grassland parcels. We considered grassland age to be the minimum age of the grassland patch at the plot location in years. Values usually ranged between 100 and 250 years.

The aerial and satellite photographs provide valuable plot-based management data, as they are usually available for several years or seasons. Radical interventions in the parcel vegetation by plowing and mowing can be usually dated and these data supplement information from landowners. Vegetation succession following abandonment or cessation of management activities can also be detected from aerial and satellite images.

Regional historical information is available from chronicle and archive materials. Chronical data mainly provides the demographic data and livestock numbers, while cadastral, konkretual (drawn up for the purpose of collecting taxes), or consolidation maps can be found in archives. The explanatory notes to these documents often contain valuable information on the historical management of individual land parcels. These data help to illustrate the context of the study region.

Along with the abovementioned sources, recent and historical literature is available on traditional agricultur- al practices, the latter mainly available in local languages only. Many pre-industrial agricultural textbooks are increasingly accessible online, as they fall out of copyright and become digitized by libraries (Burton and Riley 2018). Information on the inclusion of particular land parcels in subsidy schemes is usually available on the agricultural web portals of the respective country.

\section{Ethnological field survey on local management practices and ecological knowledge}

An anthropologist or ethnologist investigates contemporary social and cultural characteristics of a community, but also often looks into the community's history in order to understand the dynamics of the local culture. Qualitative methods are commonly used to carry out a social survey, because they are comprehensive (see Rotariu and Ilut 1997). These methods are i) observation; ii) interactive methods (such as interview, oral history, and narratives of life); and iii) ethnographic description (see Laplantine 2010, Geertz 1973). All these methods provide scientific knowledge created by means of the social interactions that happen between the researcher and the natives of a community.

The first strategic method to gather information during a field research is the observation. The goal is to understand the cultural phenomena by observing and recording as much information as possible about the social context in study locations. Direct observation implies recording (using a notebook, dictaphone, camera or video recorder) what the researcher is seeing, focusing on each detail. This means paying attention to everything that the persons who are being observed are doing. An easy example of direct observation we used during our research is the filming of the creation of a haystack, which will allow the researcher to access the information at any time afterwards. The second type of observation is participant observation (see also Spradley 1980 and Bernard 2006),

\section{0}

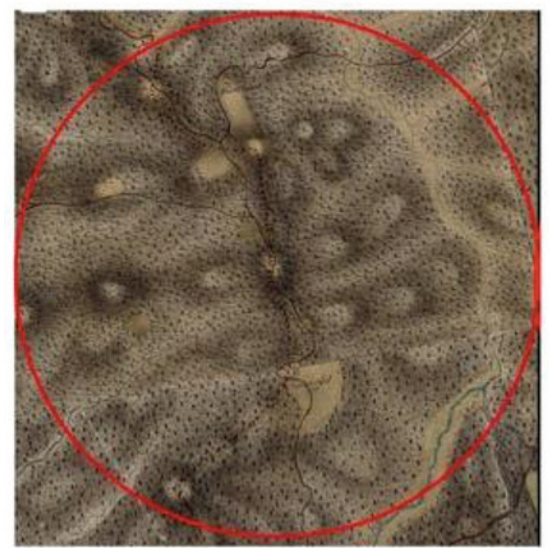

1870

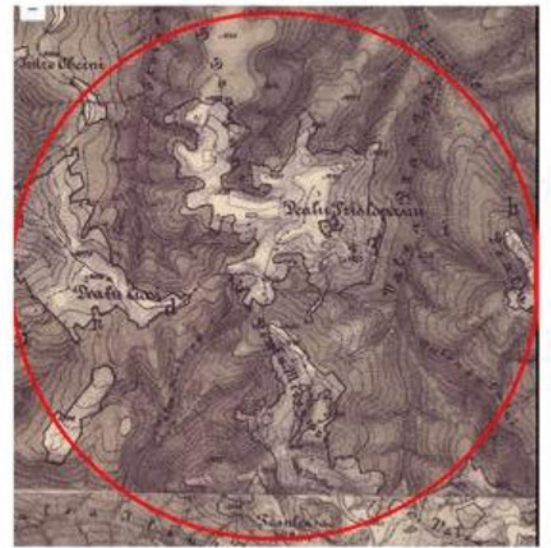

2010

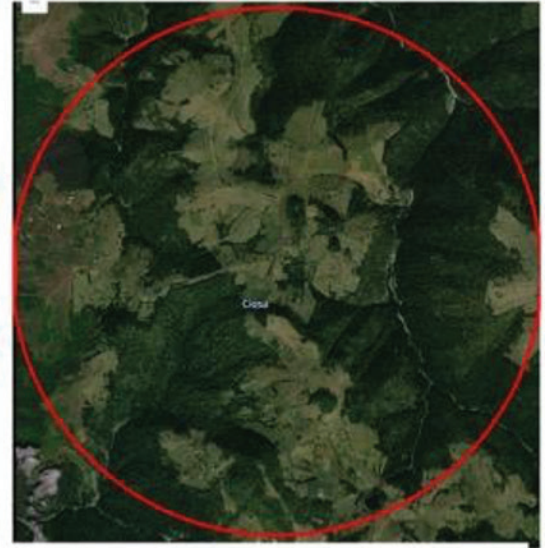

Figure 6. Historical maps and orthophotos are important sources of information about the historical and recent land use. In the picture we see the site of Ciosa (circled area) during the first (left) and second (middle) Habsburg military surveys, and in recent time (right picture). It is evident that the forest clearing occurred mostly during the last two centuries and the grassland area gradually increased. 
a contextual observation where the researcher becomes immersed in the culture (s)he is studying. Participant observation allows researchers to better understand the techniques and the actions of the community.

In order to gather local traditional ecological knowledge, interviews are frequently used, which is an interactive method that takes the form of a dialogue between the researcher and the members of the communities (see Spradley 1979, Bernard 2006). When conducting an interview, the researcher should be aware of several points. First of all, it is important for the researcher to focus on the personal experience of the interlocutor, taking into account that traditional values are usually abstract or self-implied for a member of a community, but are present in the actions that the interlocutor is describing. His/ her biography becomes the "embodiment" of tradition (Bot 2015). It is therefore recommended to avoid "general" questions, such as "What actions are done in spring to clean the meadows?" but ask, instead a more personal question, such as: "What actions do you and your family take for cleaning the meadows in spring?" In this manner, the respondent is giving an answer that (s)he knows is correct, otherwise (s)he may search in his memory for an answer that (s)he believes would please the researcher. By doing this, the interlocutor is personally involved in the interview and may find it easier to express their thoughts and experiences. Similarly, when a temporal dimension is in question, it is advisable to appeal to the respondent's own experience and memories. For example, to ascertain continuity of practices through a community, the following questions could be posed: "From whom did you learn ...?" or "Have you seen somebody else in your family that has done this/that...? Whom?" Responses to these questions could reveal the way practices are handed down or introduced from one generation to the next.

There are several types of interviews that a researcher can choose from (see Bernard 2006: 210-250). First, there is the "informal interview", which does not have a clear structure and is mainly used to establish a first contact and a preliminary discussion with the interlocutors. Usually it is not recorded, but the researcher in his field notebook writes down the interesting ideas. It can lead to an appointment for a second interview. The second type of interview is the "unstructured interview", which is done according to a broad and very flexible plan. This type of interview consists of giving a topic to a person and letting her/him talk. This type of interview is very well adapted to the narratives of life. A third type of interview, the "semi-structured interview", is the most used in ethnological surveys. In this type, the structure and the guidelines are more understandable, there are clearer topics approached, sometimes in a special order, the questions are conceived in such a manner to cover all possible aspects of the theme discussed. Some of the questions are even repeated moments later, if the topic allows it, using different words, in order to verify the coherence of the dialogue, or to stir up the memory of the interlocutor. The fourth type of interview is the "structured interview", which is frequently used in sociological surveys, applied under the form of questionnaires with questions formulated $a$ priori, where the subject responds to questions with formulated answers.

After choosing the right type of interview that would fit the research, the next challenge is to find interviewees. It is recommended that the researcher is transparent about the reasons for the research and why (s)he would like to talk with people. In order to find out the best interlocutors when the community is unknown, it is advisable to make preliminary interviews with the local key stakeholders, such as the mayor, teachers, priests, or even veterinarians as we found out in the community of Șișești (Maramureș, Romania). These people could give valuable information about their own experiences concerning the topics of the interview, but they also can point to the people whom they think are suitable to participate in the research. This is similar to the snowball sampling technique, when research participants are asked to assist in identifying other potential local experts. This method is often applied in studies of traditional ecological knowledge, since it is known that local experts within a community are acknowledged by the community (Berkes 2018). Where the researcher does not speak the local language, it is recommended to have a translator familiar with local dialect. This step is particularly important given that traditional ecological knowledge is embedded in the local speech, certain local words have different meanings in different areas and can sometimes describe different practices or ecological concepts (e.g. vegetation succession, habitats, etc.).

When conducting an interview, the researcher should ideally talk in a simple language, without using obscure or complex scientific terms that the interviewee may not understand. After explaining the reason for the interview, the researcher should first gain verbal permission for the interview to be recorded. Written permission can often be granted following the interview, once trust has been built. In some cases it is necessary to encourage the interlocutor in speaking, e.g by demonstration of importance of the information obtained, or using the probing techniques (see Bernard 2006: 217-223) that stimulate the interview, such as: the silent probe (which implies we should not rush for the interlocutor to answer); the echo probe (repeating the last thing said by the interviewee and then asking her/ him to continue; the "uh-huh" probe; the "tell-me-more" probe; and so on.

In parallel to recording the dialogue, ethnologists commonly use a notebook during interviews to write down fieldnotes (see Sanjek 1990), which may include interviewees' ideas, behaviour, emotions or other details. These notes can be a backup in case of failure to record the interview, but are also helpful as memory aids for recalling the interview content when analysing the data.

The ethnological field survey is followed by transcription and translation of the recorded interviews, and interpretation of the obtained information. It should be noted that this phase of ethnological research usually require more time than the field survey. 


\section{Question guidelines: thematic areas for investi- gation of traditional farming}

Traditional farming can be studied at several hierarchical levels, such as the land parcel, the farm, the commune or the regional/national levels. Detailed knowledge about particular land parcels is often insufficient to understand the complexity of local traditions and requires additional historical information to set it in context. In order to guide researchers in this interdisciplinary approach, we have prepared a set of questions for interviewees with different foci.

1. Topics to be addressed in the questions asked to the parcel owner related to the sampled nested plot series.

1.1. Topics related to regular grassland management: „How do you use this land parcel?":

a) Cutting grass: how many times per year is grass cut, when does cutting take place; how do you determine the right time to mow - what signs are to be found in the grass; manually or by mechanisation; mowing technique;

b) Spring grazing: when does it start, and when does it end; does it depend on the weather; how many days in this specific plot; which animals; how many animals per specific area; why grazing is performed in the particular land parcel, what effects it has upon the vegetation; is it applied regularly or occasionally; is a rotation of grazing plots used within a year/ between years; what kind of grazing is used - free, enclosure, with a shepherd, corralling (folding); is spring grazing used in combination with autumn grazing;

c) Autumn grazing: when does it start, and when does it end; does it depend on the weather; how many days in this specific plot; which animals; how many animals per specific area; why grazing is performed in the particular land parcel, what effects it has upon the vegetation; is it applied regularly or occasionally; is a rotation of grazing plots used within a year/ between years; what kind of grazing is used - free, enclosure, with a shepherd, corralling (folding); is autumn grazing used in combination with spring grazing;

d) Other types of grazing: all-year; summer; occasional (including all details as in previous points);

e) Ploughing: was the land parcel ever ploughed or harrowed; what is the date of the last ploughing; why is this land parcel suitable for crops; what crops were grown; how was the meadow/pasture restored; how long it was used for crops; was any kind of crop/grassland rotation applied, what sequence of crops was used and why; f) Sowing: have some seeds ever been added (artificial sowing) in the plot; which species; what seed mixture (local or commercial); has the local hayseed been used; have clover (Trifolium sp.), alfalfa (Medicago sp.), sainfoin (Onobrychis sp.), other legumes (Lotus corniculatus, Anthyllis vulneraria) ever been sown in the plot; if yes, why; how many seeds; how often; what are the sowing techniques; what are the effects upon the grassland quality and productivity;

g) Manuring: is the parcel manured; why; how often; when during the year; what kind of manure, was a slurry-liquid manure applied; from which animals; how to prepare a high-quality dung; what are its effects on grass quality and quantity; which plants benefit from manuring and which are suppressed; what is the application technique used; how the bedding material impacts the dung quality;

h) Artificial fertilizers: have artificial fertilizers (ammonium, nitrates, azot, marl, ash, some others) ever been applied; why; since which year; how often; when in the year; how was it applied; what are the effects on grass quality and quantity; what are the advantages and disadvantages; which plants benefit and which are suppressed;

i) Cleaning: what techniques are used to clean the meadow/pasture from shrubs, trees, stones, mosses; have weeding and cleaning from unwanted plants been applied; which plants are unwanted and why (e.g. Veratrum sp., Ononis sp., Pteridium aquilinum, Nardus stricta, mosses); has the parcel been cleaned from litter, tree leaves, branches, stones, and rocks; has the parcel been burnt for cleaning;

j) Abandonment: is the parcel managed continuously; are there periods with management interruption; when and for how many years; how abandonment affects grassland quality and productivity; what are the advantages and disadvantages of grassland abandonment;

k) Restoration: what activities improve grassland quality and productivity, what kind of restoration has taken place in the parcel; how can an abandoned grassland/ overgrazed pasture/ degraded meadow be restored; how to restore a grassland digged on the surface by wild boars;

1) Other grassland management techniques: irrigation, amelioration, anthill or molehill removal, others - details on their application.

1.2. Topics related to quality and productivity of grasslands and grassland products:

a) Hay quality: how many types of hay do you distinguish; what type of hay do you have 
from this parcel; what other types of hay do you have on your land;

b) Land parcel quality: what is the quality of this grassland, the owned land, the land in the region.

1.3.Topics related to organisation of the farm and farming activities:

a) Ownership: is the farm private or collective; if private, how many animals do you own and how big is the grassland (pastures, meadows) and cropland area of your farm; do you use external source of fodder apart from your own hay;

b) Subsidies: is the land parcel registered for subsidies; if yes, what kind of subsidy; what types of subsidies are received by the farm; what is the opinion about the subsidy system and possible improvements; what is the contribution of subsidies to the farm budget;

c) Farm organisation: how is the farm organized; what kind of grasslands do you have; do you use rotation of crops, crop-grassland or meadow-pasture rotations; what are all types of subsidies in the farm (what is your opinion about the system and what are some possible improvements, what is the contribution of subsidies to the budget); what is the level of self-sufficiency in the farm; details on marketing; rentability of small farming; ideas for improvement;

d) Haymaking and grazing system: details on spatio-temporal organization of mowing, grazing and manuring during the year; how is it related to the farm area, number of animals and distances between the parcels.

2. Questions to the parcel owners, local inhabitants and town hall officers related to farming and animal husbandry in the village/commune/region:

a) Animal husbandry in the village: how many animals do people usually have in the household; what animals; which breeds do they prefer and why; what changes happened during the last decades (increasing/decreasing number of animals);

b) Job opportunities: how many people work abroad, in the cities, how many are making a living from agriculture, how many receive subsidies for working the land or keeping animals;

c) Communal activities: are there land-use organisations or associations helping farmers with agricultural topics; if yes, how do they help; is there communal activity planning and common land use organisation; describe if something like that exists;

d) Pastures in the village: what types of pastures are present in the village, e.g. private (close or remote), common (close or remote); what is the grazing system, e.g. free grazing, fencing, herded pastures; are some parts of pastures cut for hay; where and according to which criteria were the pastures established; are they compact or dispersed; details on pasture cleaning and other private or communal activities; does the livestock in the village graze outside the stables during the year and how long (in weeks or months); how long the livestock stays in stables (details on different types of livestock);

e) Meadows in the village: where and according to which criteria were the meadows established; are they compact or dispersed; what types of meadows can be distinguished according to grass quality, management practices, distance from the settlement, other criteria; are some activities prohibited on meadows before haymaking (animal or people access, collecting mushrooms, herbs, other); is haymaking an individual or a collective activity; how is it organised; which types of hay storage constructions are used; hay transport and haymaking details (if interesting); what is the main difference between the historical and recent meadow management;

f) Wintering of animals and winter fodder: where the animals are housed in winter (in the village or in remote areas); how long (in weeks or months); which types of winter fodder are used in the village, e.g. hay, silage, pollarded trees and shrubs, compound feed; is additional fodder used from outside the village; what materials are used for bedding in the stables; details (and terminology) on summer or winter stables, field and meadow stables outside the village, if used;

g) Borders and boundaries: distinguishing and marking borders between the properties (fences, hedges, allees, stones, others);

h) Introduced customs: which farming customs are old and which are modern; which have local origin, and which were introduced; when were they introduced and why; have new grass or herb species been introduced to the village and when.

3. Questions to local inhabitants with experience of local farming traditions and willing to share personal ecological knowledge:

a) Haymaking details: how the mowing time affects the hay and the meadow; do you practice rotation of mowing times on different meadows and why; what kind of weather is best for hay production; what adaptations are necessary in years with bad weather; 
b) Mulching: what happens if the cut grass is left on the parcel (is not removed, which is the principle of mulching); is the quality of mulched grassland sufficient/decreasing or increasing in time; which plants are sensitive to mulching; is mulching better for grassland quality and productivity than leaving the grass standing for one year, two years, burning, or other technique of cleaning; is the spring mulching better for grassland quality and productivity than the autumn mulching;

c) Burning: are some meadows burned in the village; when (in spring, autumn, which month) and why; how does burning affect the grassland quality and productivity;

d) Transhumance: does/did some transhumance grazing occur in the region; where in the village area; who is/was passing in transhumance (sheep owners from the village, from other regions);

e) Grazing in forest: are/were the forests in the village grazed; which animals graze in the forest and at what time of year; what are the effects of forest grazing for the animals and for the forests;

f) Trees in grassland: can you give details on usage of trees in grasslands, advantages and disadvantages; is/was pollarding used for getting winter-fodder; which trees; details on harvesting and application;

g) Cultivation of legumes: when was legume (clover, alfalfa, sainfoin or other) cultivation introduced in the village; how are/were the legumes cultivated and harvested; where is/ was the seed obtained from; what are the advantages of legume cultivation;

h) Influence of the political system: was grassland management affected by communism (collectivisation, land consolidation, abandonment, change in crop priorities), if yes, when (years) and how; was grassland management affected by the political changes in post-communist era (end of collective farms and cooperatives, abandonment, change in crop priorities, migration of inhabitants abroad, other), if yes, when (years) and how;

i) Landscape change: how has the region changed since the days of your grandparents; what is your reception of positive and negative trends in the landscape development (e.g. succession, invasive species);

j) Vegetation change: which plant species became extinct or decreased in the village; which plant species are newly appearing or increasing in number/cover; which habitats are occupied by exotic, non-native species; are these species desired or unwanted; what means may be used to eradicate the particular unwanted species.

4. Questions related to age of the settlements and grassland parcels to be answered from historical documents:

a) Age of the village: how old is the village/settlement;

b) Grassland age: when was the forest cleared/ burned and the grazing/mowing regime established; from which century do the oldest records on traditional grassland management come from;

c) Ethnic groups: what are the main ethnic groups in the village/settlement; have other ethnic groups influenced grassland utilisation in the past or in recent times;

d) Demography: is the number of inhabitants in the village the same/lower/ higher in comparison to $1900,1950,2000$; is the proportion of inhabitants living from agriculture the same/lower/higher in comparison to 1900, 1950, 2000;

e) Animal numbers: is the current number of livestock in the village the same/lower/higher in comparison to $1900,1950,1980,1990$, 2000, 2010, 2020 (what are the figures for cows, sheep and goats, horses, pigs separately);

f) Area of agricultural land: is the current pasture/cropland/meadow area the same/ decreasing/increasing in comparison to 1900/1950/2000.

\section{Pros and Cons of our study approach}

Pro 1: Teamwork enriches each of the participants

Participation of researchers from several disciplines allows for new insights and addresses the multifunctionality of traditional farming landscapes as a study object.

Pro 2: Clear, detailed and unified methodology used for a huge area

The value of the data increases with the size of the area on which the method is applied. Methods with a similar degree of detail have so far been applied only locally, often without the possibility of comparison with other areas.

\section{Pro 3: Simple but robust sampling design}

Thanks to the stratified random plot selection, the data are suitable for estimation of multiple diversity parameters. Species richness can be estimated at seven increasing spatial scales, while beta diversity and species pool can be estimated at the site level. 
Pro 4: Question guidelines are provided for ethnobotanical studies focussing on traditional farming

Our question guide was prepared by botanists and anthropologists in collaboration and both natural and social sciences qualifications were valued equally in its production. It is widely applicable in both disciplines.

Pro 5: Historical and landscape information opens new horizons

Including historical and landscape information allows evaluation of vegetation change from new perspectives. History, landscape context, and management are increasingly seen by environmental scientists as key for understanding grassland biodiversity.

\section{Pro 6: Keeping valuable local ecological knowledge}

Continuous abandonment of traditional agricultural practices across Europe raises concerns for the loss of traditional ecological knowledge (TEK; Burton and Riley 2018). TEK represents a cumulative body of knowledge practice and beliefs concerning environmental management, specifically agricultural management in Europe that supposedly developed through generations of interaction between local communities and their environment. Recording TEK is crucial to preserve the cultural heritage of each investigated region.

Pro 7: Estimating significance of management practices at the plot level

Gathering both vegetation and management data for all the plots allows for proofing the importance of particular management methods for biodiversity values.

\section{Pro 8: Capturing the grassland dynamics}

In contrast to phytosociological sampling based on a single visit of the sampled area, our approach tries to capture the vegetation development by asking about the past. This methodology proves the dynamic management of grasslands, since it records precise agricultural practices that were carried out by individual farmers on the grasslands they own. Moreover, it shows how the continuity or discontinuity in traditional grassland management may correlate with current biodiversity patterns.

\section{Con 1: It is labourious and time consuming}

The interview protocol was developed during the three years of our project. It was clear from the beginning that it is not possible for a single team to perform both the vegetation sampling and the interviews in numerous study sites, as the period between flowering of the grasses and the first cut is too short and also because the interviews need special skills to obtain high quality information. We started with a collection of questions to determine the workflow associated with the management of local grasslands by consulting agricultural workbooks (Klapp 1965; Opitz von Boberfeld 1994). We began with more than 100 questions (including over 70 questions to the landowners) and reduced them during the following years to those questions that connected with the plot biodiversity.

Experience has shown that with good logistics, it is possible to carry out the vegetation survey part of our methodology on one study site in three days, concentrating on two land parcels (and nested plot series) per day. However, more than one visit to communities was necessary in order to carry out the anthropological part of our methodology (e.g. in certain situations where the local people do not have time to respond due to their daily activities, the researcher has to come back another time and try again). We found that the research team should ideally consist of two anthropologists to support each other in data collection particularly when the study site is new to the researchers. The best strategy is to make two teams, the anthropologists and the biologists, logistically independent, so that they can work together, but also in different places during a single day: either to go to the sampling parcel and to ask about the specific management practices for that very place, or to return to the village if there are no people nearby the parcel, or to stay in the settlement, visit the town hall and to take interviews that would provide more context concerning the local practices in general. Spending more time with the local communities would help the researchers to understand better the local practices and find suitably knowledgable interviewees.

Con 2: It is concise and thus not always covering all important aspects

By focusing only on specific parcels in the landscape where the vegetation surveys are carried out, researchers may miss the wider picture of the agricultural practices and landscape management of the community. It is therefore recommended to integrate individual site-specific management with the wider agricultural and economic activities at the landscape level. Some of the activities at this level are organized by the community according to their own local rules. Consequently, it is usually necessary to obtain additional oral or historical information on the common use of resources in the recent past.

\section{"Grassland with Tradition" database}

The database "Grassland with Tradition" is registered in Global Index of Vegetation-Plot Databases (GIVD, https://www.givd.info/faces/database_details.xhtml) with the identifier ID EU-00-032. As to 31 October 2020 


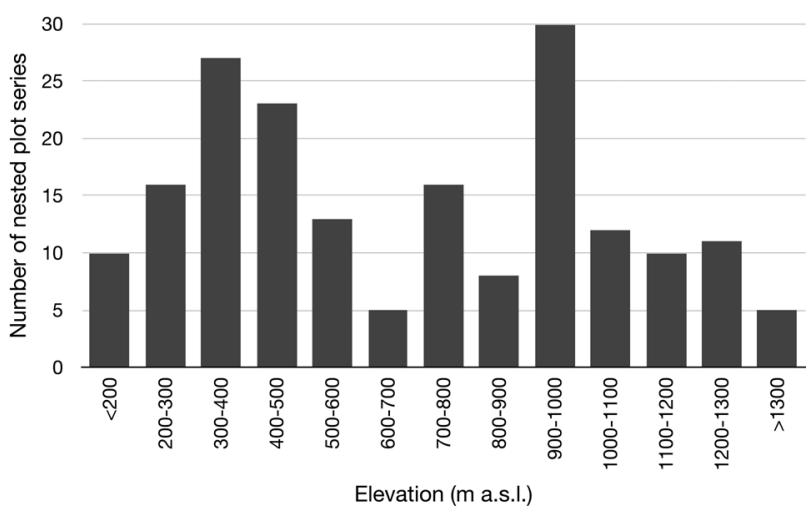

Figure 7. "Grassland with Tradition" database: Distribution of nested plot series along the elevation gradient (as to 31 October 2020).

it contains 186 nested plot series recorded in the Carpathian Mountains within seven different countries. The sampling was conducted during 2017-2020. The sampled plots are distributed at elevation between 147 and $1422 \mathrm{~m}$ (Figure 7) and over various geological bedrock types including plutonic and volcanic rocks, limestone, flysch, loess, and sediments (Table 1). The main land-use categories (meadows, pastures and abandoned land) are further divided according to the combination of applied management practices (Figure 8). The meadows include five basic categories regarding the additional application

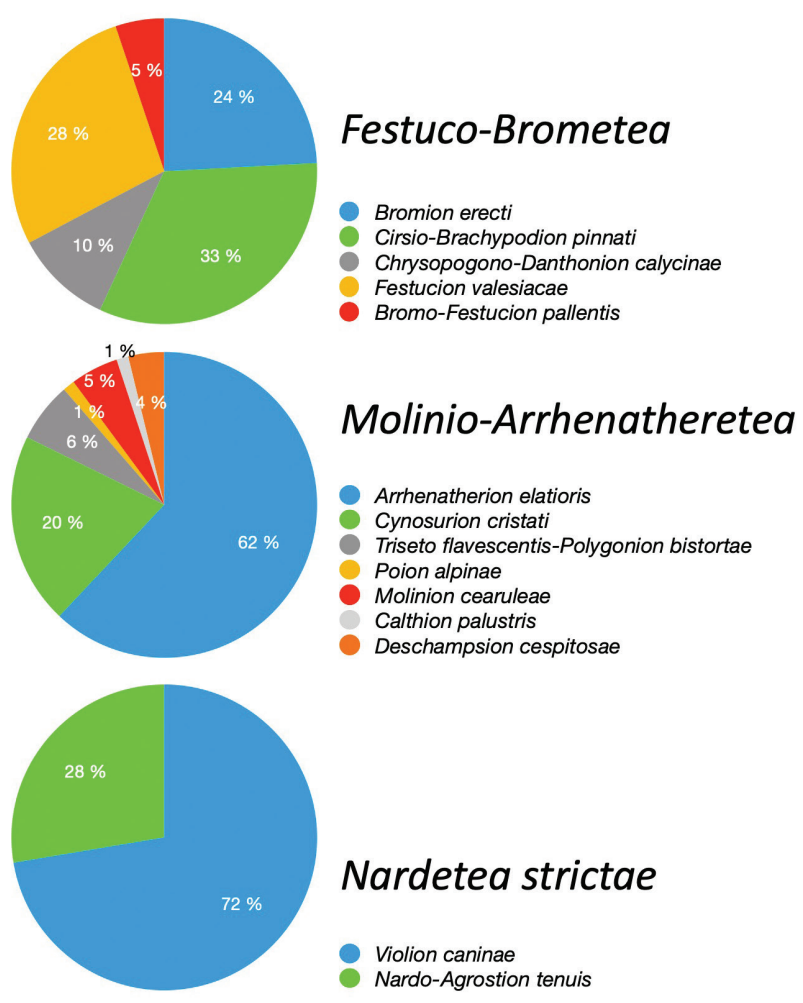

of ploughing and grazing, and its timing. Permanent meadows were never ploughed and are used exclusively by regular mowing. Meadows on former cropland include grassland in active crop-grassland rotation systems or older fallows which are now used exclusively as meadows. Three types of grazed meadows can be distinguished, either with exclusive spring or autumn grazing and those grazed during both these periods. In the regions with best-preserved farming traditions (Figure 9) grazed medows represent the absolute majority of local meadow types. Most of the sampled pastures are used for grazing cows or sheep as single grazing animal (Figure 8). Regarding the phytosociological affiliation (Table 1, Figure 8), mesic grasslands of the Arrhenatherion elatioris alliance (Molinio-Arrhenatheretea class) and Violion caninae (Nardetea strictae class) prevail, followed by semidry grasslands of the Bromion erecti and Cirsio-Brachypodion alliances (Festuco-Brometea class). According to the actual land-use consulted with the landowners we distinguished three categories of grassland management: i) management according to continuous living tradition, ii) management according to modified tradition, and iii) management not based on tradition. Although the classification criteria of traditional land-use are sometimes fuzzy and subjective, there is a clear decreasing trend of traditional farming along the Carpathian arch from the southeast to the northwest (Figure 9).

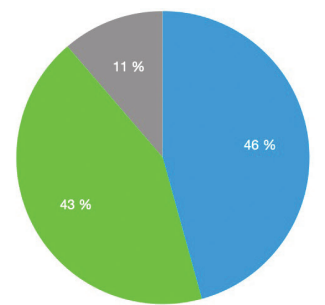

LAND-USE CATEGORIES

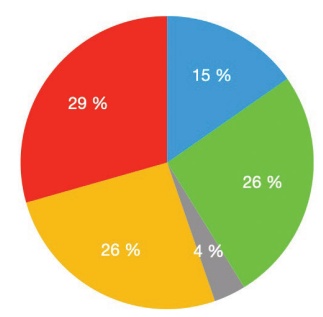

\section{MEADOWS}

Permanent meadow

Meadow on former cropland

Grazed meadow (spring grazing)

Grazed meadow (spring and autumn grazing)

Grazed meadow (autumn grazing)

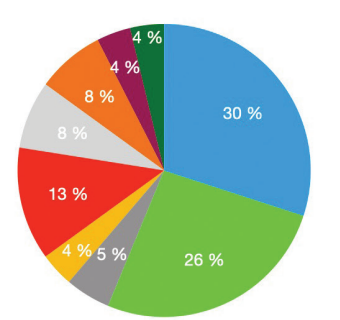

\section{PASTURES}

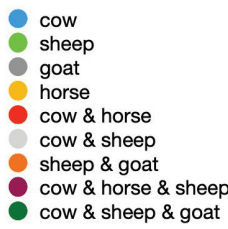

Figure 8. "Grassland with Tradition" database: Representation (as to 31 October 2020) of i) grassland syntaxa (phytosociological classes and alliances); ii) land-use categories; iii) types of meadows according to the presence/ absence of additional management by ploughing and grazing; iv) types of pastures according to grazing animal(s). 


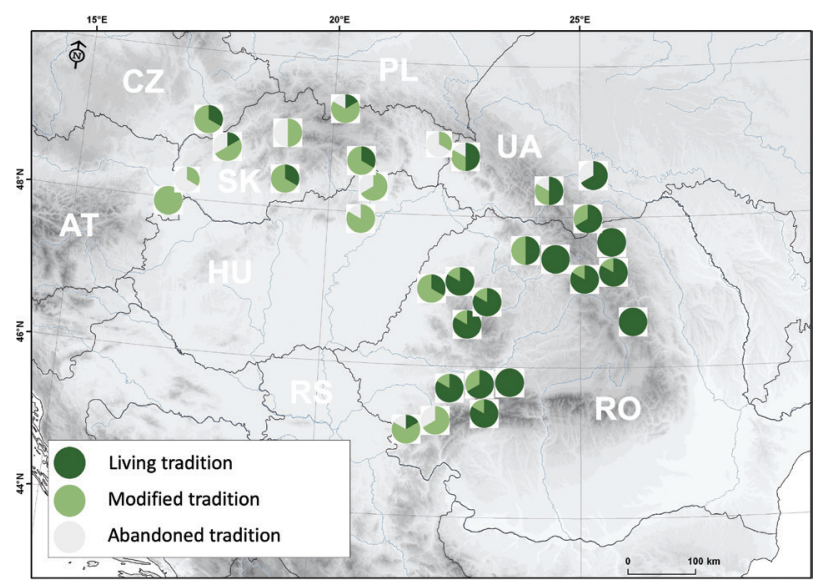

Figure 9. "Grassland with Tradition" database: Distribution of living, modified, and abandoned tradition in grassland management of the sites studied so far (as to 31 October 2020). In each study site, six parcels were selected by a stratified random selection considering the topographic situation (aspect and slope) and habitat type (managed grassland). According to the actual land-use type on those parcels (consulted with the landowners) we distinguished three categories of grassland management: i) management according to continuous living tradition, ii) management according to modified tradition, and iii) management not based on tradition. Although the classification criteria of traditional land-use are sometimes fuzzy and subjective, clear differences in farming approaches are obvious between the Western and Eastern Carpathians.

\section{Author contributions}

M.J. conceived the idea, edited and analysed the database, and outlined the first draft of the text; M.J. and

\section{References}

Akeroyd J, Page N (2006) The Saxon Villages of Southern Transylvania: Conserving Biodiversity in a Historic Landscape. In: Gafta D, Akeroyd J (Eds) Nature Conservation. Environmental Science and Engineering (Environmental Science). Springer, Berlin, Heidelberg, DE, 199-210. https://doi.org/10.1007/978-3-540-47229-2_21

Akeroyd J, Page N (2011) Conservation of High Nature Values (HNV) grassland in farmed landscape in Transylvania, Romania. Contribuții Botanice 46: 57-71.

Antipa G (1916) Pescăria și pescuitul în România [Fisheries and fishing in Romania]. Librăriile Socec \& Comp, C. Sfetea, Pavel Suru. București, RO, 794 pp.

Babai D, Molnár Z (2014) Small-scale traditional usement of highly species-rich grasslands in the Carpathians. Agriculture, Ecosystems \& Environment 182: 123-130. https://doi.org/10.1016/j. agee.2013.08.018

Babai D, Molnár Z (2016) Species-rich Mountain Grasslands Through the Eyes of the Farmer: Flora, Species Composition, and Extensive Grassland Management. Martor 21: 147-169.
M.M. developed and described the botanical and A.I. and C.M.I. the ethnological parts of the methodology; all authors participated in the fieldwork, contributed to the database, discussed and commented on the previous versions of the manuscripts.

\section{Acknowledgements}

Financial support for the fieldwork was provided by the National Geographic Society, grant NGS-288R-18 on "Carpathian grasslands - genuine celebration of cultural and natural diversity", and by the Slovak Academy of Sciences, grant VEGA 2/0095/19 on "Traditional ecological knowledge for grassland conservation and restoration". We thank all people who contributed to the fieldwork, plant identification, analyses or logistics: Anna Bérešová, Alina Sorina Biro, Lubov Borsukiewicz, Vasyl Budzhak, Michał Chiliński, Illya Chorney, Iwona Dembicz, Katarína Devánová, Daniela Dúbravková, Thorsten English, Karel Fajmon, Alessandra Fidelis, Lara Gartler, Loredana Grill, Ivana Jongepierová, Roman Kish, Mykhailo Khytruk, Łukasz Kozub, Svatava Kubešová, Jan Kučera, Ina Kvakovska, Anna Kuzemko, Ihor Kuzemko, Lukáš Laffers, Silvia Maráková, Katarzyna Nurowska, Salza Palpurina, Yordan Palpurin, Harald Rötzer, András Schmotzer, Dariia Shyriaeva, Katarína Skokanová, Imelda Somodi, Pavel Širka, Iveta Škodová, Róbert Šuvada, Alla Tokaryuk, Eva Uhliarová, Viktor Virók, Denys Vynokurov, Susan Wiser. We thank Emmeline Topp for linguistic editing of the manuscript. Special thanks go to local farmers and inhabitants for their hospitality and sharing their knowledge, food, and other resources.

Bărbat A (1944) Drăguş, un sat din Ţara Oltului (Făgăraş): manifestări economice: structura economică a satului. [Drăguș a village from Olt Land: economic activities and the economic structure of the village]. Institul de Științe sociale al României, Bucharest, RO, 188 pp.

Berkes F (2018) Sacred Ecology. Taylor \& Francis Group, Routledge, NY, US, 368 pp. https://doi.org/10.4324/9781315114644

Bernard RH (2006) Research Methods in Anthropology. Qualitative and Quantitative Approaches. Altamira Press, Lanham, NY, US, 824 pp.

Bernea E (1985) Cadre ale gîndirii populare românești: contribuții la reprezentarea spațiului, timpului și cauzalității [Frames of popular Romanian thought: contributions to the representations of space, time and causality]. Cartea Românească, Bucharest, RO, 316 pp.

Biró É, Babai D, Bódis J, Molnár Z (2014) Lack of knowledge or loss of knowledge? Traditional ecological knowledge of population dynamics of threatened plant species in East-Central Europe. Journal of Nature Conservation 22: 318-325. https://doi.org/10.1016/j.jnc.2014.02.006 Boiko I (2008) Sushinnia travy ta zberihannia sina v ukrainskykh ta slovatskykh Karpatakh (XX poch. XXI st.) [Drying of grass and storage 
of hay in the Ukrainian and Slovak Carpathians (XX century beg. of the XXI century)]. Narodoznavchi zoshyty 3-4: 228-252.

Boiko I (2009a) Sporudy dlia zberihannia sina ta solomy v ukrainskykh, polskykh ta slovatskykh Karpatakh (XX poch. XXI st.) [Buildings for storing hay and straw in the Ukrainian, Polish and Slovak Carpathian Mountains (XX century - beg. of the XXI century)]. Fortetsia 1:531-549.

Boiko I (2009b) Kul'tura zagotovki sena v Slovatskikh i Ukrainskikh Karpatakh (etnoekologicheskiy aspekt) [Haymaking culture in Slovak and Ukrainian Carpathians (ethnoecological aspect)]. In: Etnos i sreda obitaniya. Sbornik etnoekologicheskikh issledovaniy k 85-letiyu V. I. Kozlova, Moscow, RU, 281-311.

Boiko I, Łach J (2020) Glade farming as a product and a factor in the formation of landscape (using the example of the Boikivshchyna Region in the Ukrainian Carpathians). Dissertations of Cultural Landscape Commission 43: 73-96.

Bonn S, Poschlod P (1998) Ausbreitungsbiologie der Pflanzen Mitteleuropas. Quelle \& Meyer, Wiesbaden, DE, 404 pp.

Borza A (1935) Contribuții la flora Basarabiei [Contribution to Basarabian flora]. Buletinul Grădinii Botanice și al Muzeului Botanic dela Universitatea din Cluj 15 (1-4): 233-236.

Borza A [Ed.] (1968) Dicționar etnobotanic cuprinzând denumirile populare românești și în alte limbi ale plantelor din România [Ethnobotanical Dictionary with popular names in Romanian and other languages of plants in Romania]. Editura Academiei R.S.R., Bucharest, RO, $315 \mathrm{pp}$.

Bossard M, Feranec J, Otahel J (2000) CORINE Land Cover Technical Guide -Addendum 2000. European Environmental Agency, Copenhagen, DK, $105 \mathrm{pp}$.

Bot N (2015) Baba Ruța și povestea ei sau despre autenticitatea documentului etnologic [The Old Ruța Lady and her story, or discussing the authenticity of ethnologic document]. In Hedeșan O, Folclorul, ce facem cu el? Editura Universităţii de Vest, Timișoara, RO, 181-186.

Burton R, Riley M (2018) Traditional Ecological Knowledge from the internet? The case of hay meadows in Europe. Land Use Policy 70: 334-346. https://doi.org/10.1016/j.landusepol.2017.10.014

Bürgi M, Dalang T, Holderegger R, Diacon-Bolli J (2013) Die Nutzungsgeschichte der Halbtrockenrasen ist entscheidend für den Erhalt ihrer Artenvielfalt. Anliegen Natur 35: 40-43.

Butură V (1978) Etnografia poporului român: cultura materială [Romanian people ethnography: material culture]. Editura Dacia, Cluj-Napoca, RO, 465 pp.

Butură V (1979) Enciclopedie de etnobotanică românească [Encyclopaedia of Romanian Ethnobotany]. Editura Științifică și Enciclopedică, Bucharest, RO, 282 pp.

Conea I (1940) Clopotiva: un sat din Hațeg: monografie sociologică întocmită de Echipa Regală Studențească 19/935 sub conducerea lui Ion Conea [Clopotivă: a village from Hațeg: sociological monograph of the Royal Studant Team 19/935, conducted by Ion Conea]. Institutul de Științe Sociale al României, Bucharest, RO, 303 pp.

Dahlström A, Iuga A, Lennartsson T (2013) Managing biodiversity rich hay meadows in the EU: a comparison of Swedish and Romanian grasslands. Environmental Conservation 40: 194-205. https://doi. org/10.1017/S0376892912000458

Dengler J, Boch S, Filibeck G, Chiarucci A, Dembicz I, Guarino R, Henneberg B, Janišová M, Marcenò C, ..., Biurrun I (2016) Assessing plant diversity and composition in grasslands across spatial scales: the standardised EDGG sampling methodology. Bulletin of the Eurasian Grassland Group 32: 13-30.
Diacon-Bolli JC, Dalang T, Holderegger R, Bürgi M (2012) Heterogeneity fosters biodiversity - linking history and ecology in dry calcareous grasslands. Basic and Applied Ecology 13: 641-653. https://doi. org/10.1016/j.baae.2012.10.004

Drăgulescu C (2013) Botanica populară românească în sudul Transilvaniei [Romanian Folk Botany in Southern Transylvania]. Editura Universităţii Lucian Blaga, Sibiu, RO, 607 pp.

Filipașcu A (1981) Expediții la noi acasă [Expeditions in our homeland]. Editura Dacia, Cluj-Napoca, RO, 168 pp.

Fruntelată I, Mușa C, Dudău E (2016) Haylife and Haylore in Starchiojd (Prahova county, Romania): from Present to Past. Martor 21: 87-100.

Geertz C (1973) Thick Description: Toward an Interpretative Theory of Culture. In: Geertz C (Ed.) Interpretation of Cultures. Selected Essays, Basic Books, Inc. Publishers, NY, US, 3-30.

Halada L, Evans D, Romão C, Petersen JE (2011) Which habitats of European importance depend on agricultural practices? Biodiversity and Conservation 20: 2365-2378. https://doi.org/10.1007/s10531011-9989-z

Hartel T, Craioveanu C, Réti K-O (2016) Tree Hay as Source of Economic Resilience in Traditional Social-ecological Systems from Transylvania. Martor 21: 53-6.

Hejcman M, Hejcmanová P, Pavlů V, Beneš J (2013) Origin and history of grasslands in Central Europe - a review. Grass and Forage Science 68: 345-363. https://doi.org/10.1111/gfs.12066

Hijmans RJ, Cameron SE, Parra JL, Jones PG, Jarvis A (2005) Very high resolution interpolated climate surfaces for global land areas. International Journal Climatology 25: 1965-1978. https://doi. org/10.1002/joc. 1276

Ionică I (1943) Dealu Mohului: ceremonia agrară a cununii în Țara Oltului [Mohu's Hill: the agrarian ceremony of the wreath in Oltului County]. Tipografia "Bucovina" I. E. Toroutiu, Bucharest, RO, 352 pp. Iuga A (2016) Intangible Hay Heritage in Șurdești. Martor 21: 67-84.

Ivașcu CM (2018) Cunoștințe ecologice tradiționale și adaptări bio-culturale în comuna Ieud, o străveche așezare din Țara Maramureșului [Traditional Ecological Knowledge and Bio-Cultural adaptations in Ieud, An Ancient Settlement from Maramureș County]. Ph.D. thesis, Babeş-Boyai University, Cluj-Napoca, RO, 252 pp.

Ivașcu CM, Öllerer K, Rákosy L (2016) The Traditional Perceptions of Hay and Hay-Meadow Management in a Historical Village from Maramureş County, Romania. Martor 21: 39-51.

Janišová M, Biro A, Iuga A, Širka P, Škodová I (2020) Species-rich grasslands of the Apuseni Mts (Romania): role of traditional farming and local ecological knowledge. Tuexenia 40: 409-427.

Johansen L, Westin A, When S, Iuga A, Ivașcu CM, Kallioniemi E, Lennartsson T (2019) Traditional semi-natural grassland management with heterogeous mowing times enhances flower resources for pollinators in agricultural landscape. Global Ecology and Conservation 18: e00619. https://doi.org/10.1016/j.gecco.2019.e00619

Klapp E (1965) Grünlandvegetation und Standort. Parey, Berlin und Hamburg, DE, 384 pp.

Kopczyńska-Jaworska B (1959) Materiálie k štúdiu pastierstva na Slovensku [Materials for study of pastoralism in Slovakia]. Slovenský národopis 7: 387-432.

Kopczyńska-Jaworska B (1961) Das Hirtenwesen in den Polnischen Karpaten. In: Földes L. (Ed.) Viehzucht und Hirtenleben in Ostmitteleuropa. Akadémiai Kiadó, Budapest, HU, 389-431.

Kubijovyč V (1936) Pastýřský život v Podkarpatské Rusi [Shepherds' life in the Carpathian Ruthenia]. Zeměpisné práce 8: 77-79. 
Kun R, Bartha S, Malatinszky Á, Molnár Z, Lengyel A, Babai D (2019) „Everyone does it a bit differently!”: Evidence for a positive relationship between micro-scale land-use diversi-ty and plant diversity in hay meadows. Agriculture, Ecosystems \& Environment 283: 106556. https://doi.org/10.1016/j.agee.2019.05.015

Laplantine F (2010) La description ethnographique. Armand Colin, Paris, FR, $128 \mathrm{pp}$.

Marian SF (1994) Sărbătorile la români: studiu etnografic [Romanian feasts: ethnographic study]. Vol. 1-2, Editura Fundației Culturale Române, Bucharest, RO, 359 pp.

Marian SF (2008-2010) Botanica poporană română [Popular Romanian Botany]. Vol. 3, Musatinii, Suceava, RO, 712 pp.

McCune B (2007) Improved estimates of incident radiation and heat load using non-parametric regression against topographic variables. Journal of Vegetation Science 18: 751-754. https://doi. org/10.1111/j.1654-1103.2007.tb02590.x

Molnár Z, Gellény K, Margóczi K, Biró M (2015) Landscape ethnoecological knowledge base and management of ecosystem services in a Székely-Hungarian pre-capitalistic village system (Transylvania, Romania). Journal of Ethnobiology and Ethnomedicine 11: 3. https:// doi.org/10.1186/1746-4269-11-3

Mucina L, Bültmann H, Dierßen K, Theurillat J-P, Raus T, Čarni A, Šumberová K, Willner W, Dengler J, ..., Tichý L (2016) Vegetation of Europe: Hierarchical floristic classification system of vascular plant, bryophyte, lichen, and algal communities. Applied Vegetation Science 19 (Suppl. 1): 3-264. https://doi.org/10.1111/avsc.12257

Opitz von Boberfeld W (1994) Grünlandlehre - Biologische und ökologische Grundlagen [UTB Taschenbuch 1770]. Ulmer, Stuttgart, DE, $336 \mathrm{pp}$.

Pamfile T (1997) Sărbătorile la români: studiu etnografic [Romanian feasts: ethnographic study]. Saeculum, Bucharest, DE, 431 pp

Plieninger T, Hartel T, Martín-López B, Beaufoy G, Bergmeier E, Kirby K, Montero MJ, Moreno G, Oteros-Rozas E, Van Uytvanck J (2015) Wood-pastures of Europe: Geographic coverage, social-ecological values, conservation management, and policy implications. Biological Conservation 190: 70-79. https://doi.org/10.1016/j.biocon.2015.05.014

Podolák J (1961) Pasienkové a lúčne hospodárenie na Hornom Pohroní [Pasture and meadow management in the Upper Hron Valley]. Slovenský Národopis 9: 549-578.

Podolák J (1962) Spôsoby chovu hospodárskych zvierat. Návod na etnografický výskum [Methods of livestock breeding. Guidelines for ethnographic research]. Vydavatelstvo SAV, Bratislava, SK, 182 pp.

Podolák J (1965) Pestovanie polnohospodárskych plodín a chov hospodárskych zvierat na Slovensku od polovice 19. do polovice 20. storočia [Cultivation of agricultural crops and livestock farming in Slovakia from the mid- $19^{\text {th }}$ to the mid- $20^{\text {th }}$ century]. Agrikultúra 4: 29-77.
Podolák J (1966) Poloninské hospodárstvo Huculov v Ukrajinských Karpatoch [Glade farming of Hutsuls in the Ukrainian Carpathians]. Slovenský národopis 2: 193-292.

Podolák J (2008) Tradičné polnohospodárstvo na Slovensku [Traditional agriculture in Slovakia]. ASCO art \& science, Bratislava, SK, 435 pp.

Poschlod P (2015) Geschichte der Kulturlandschaft, Verlag Eugen Ulmer, Stuttgart, DE, 320 pp.

Poschlod P, Baumann A, Karlik P (2009) Origin and development of grasslands in Central Europe. In: Veen P et al. (Eds) Grasslands in Europe of high nature value. KNNV Publishing, Zeist, NL, 15-25. https://doi.org/10.1163/9789004278103_003

Poschlod P, WallisDeVries MF (2002) The historical and socioeconomic perspective of calcareous grasslands - lessons from the distant and recent past. Biological Conservation 104: 361-376. https://doi. org/10.1016/S0006-3207(01)00201-4

Rotariu T, Iluț P (1997) Ancheta sociologică și sondajul de opinie [Sociological Inquiry and Survey]. Polirom, Iași, RO, 216 pp.

Sanjek R (1990) Fieldnotes. The Makings of Anthropology. Cornell University Press, London, UK, 432 pp. https://doi. org/10.7591/9781501711954

Sõukand R, Pieroni A (2016) The importance of a border: Medical, veterinary, and wild flood ethnobotany of the Hutsuls living on the Romanian and Ukrainian sides of Bukovina. Journal of Ethnopharmacology 185: 17-40. https://doi.org/10.1016/j.jep.2016.03.009

Spradley JP (1979) The Ethnographic Interview. Harcourt Brace Jovanovich College Publishers, NY, US, 247 pp.

Spradley JP (1980) Participant observation. Harcourt Brace Jovanovich College Publishers, NY, US, 195 pp.

Špulerová J, Kruse A, Branduini P, Centeri C, Eiter S, Ferrario V, Gaillard B, Gusmeroli F, Jurgens S., ..., Öllerer K (2019) Past, Present and Future of Hay-making Structures in Europe. Sustainability 11: e5581. https://doi.org/10.3390/su11205581

Timár G, Biszak S, Székely B, Molnár G (2010) Digitized maps of the Habsburg military surveys - overview of the project of ARCANUM Ltd. (Hungary). In: Jobst M (Ed.) Preservation in digital cartography. Springer, Berlin, DE, 273-283. https://doi.org/10.1007/978-3-64212733-5_14

Tyvodar M (1994) Tradycijne skotarstvo Ukrajins'kyx Karpat druhoji polovyny XIX - peršoji polovyny XX st.: istoryko-etnolohične doslidžennja. [Traditional cattle breeding in the Ukrainian Carpathians of the second half of the XIX - first half of the XX century: historical and ethnological research]. Karpaty, Uzhhorod, UA, 556 pp.

Vuia R (1964) Tipuri de păstorit la români [Romanian shepherding systems]. Editura Academiei R.S. Române, Bucharest, RO, 252 pp.

Wehn S, Westin A, Johansen L, Iuga A, Ivașcu CM, Kallioniemi E, Lennartsson T (2019) Data on flower resources for pollinators in Romanian semi-natural grasslands mown at different time. Data in Brief 25: e104065. https://doi.org/10.1016/j.dib.2019.104065

\section{E-mail and ORCID}

Monika Janišová (Corresponding author, monika.janisova@gmail.com), ORCID: https://orcid.org/0000-0002-6445-0823

Anamaria Iuga (anaiuga@gmail.com), ORCID: https://orcid.org/0000-0002-9516-2672

Cosmin Marius Ivașcu (cosmin.ivascu@e-uvt.ro)

Martin Magnes (martin.magnes@uni-graz.at), ORCID: https://orcid.org/0000-0002-5453-5735 